STUDIA PRAWNO-EKONOMICZNE, T. CXIII, 2019

PL ISSN 0081-6841; e-ISSN 2450-8179 s. 103-116

https://doi.org/10.26485/SPE/2019/113/6

\title{
Eliza MANIEWSKA*
}

iD https://orcid.org/0000-0002-8101-7351

\section{MODEL STOSUNKU PRACY A PROJEKT KODEKSU PRACY Z 2018 R.}

\begin{abstract}
Abstrakt
Przedmiot badań: Perspektywy badawcze przyjmowane w polskiej i europejskiej nauce prawa pracy odnośnie do modelu stosunku pracy (modelu stosunku świadczenia pracy).

Cel badawczy: Określenie pożądanych perspektyw formułowania modelu stosunku pracy i zestawienie ich z propozycją zmiany modelu stosunku pracy zawartej w projekcie kodeksu pracy z $2018 \mathrm{r}$.

Metoda badawcza: Autorka posługuje się metodą mieszaną, uwzględniając obok metody formalno-dogmatycznej także metody: prawno-porównawczą, filozoficzną i antropologiczną.

Wyniki: Autorka wskazuje, jakie - jej zdaniem - powinny być perspektywy formułowania propozycji zmian modelu stosunku pracy w polskim prawie pracy. Uważa, że należy przyjąć perspektywę holistyczną uwzględniającą głównie: prawa człowieka (prawa socjalne), uwarunkowania antropologiczne, wartości moralne, czynniki wynikające z procesów gospodarczych, a także normatywne uregulowania ustroju gospodarczego w wymiarze krajowym i europejskim oraz ogólnoświatowym. Postuluje, aby żadna z wymienionych perspektyw nie była dominująca lub nadmiernie dominująca. Niezbędne jest bowiem podejście zrównoważone. Pożądany model stosunku pracy nie powinien również abstrahować od nowych form kontroli i nowych (także technologicznych) narzędzi podporządkowywania sobie pracownika przez pracodawcę. Niezbędne jest również pozostawienie ludziom wyboru, czy i w jakim stopniu chcą być podporządkowani zatrudniającemu.

Biorąc to pod uwagę, autorka odnosi się do wybranych elementów modelu stosunku pracy wyłaniającego się z propozycji zawartych w projekcie kodeksu pracy z 2018 r. Zarzuca, iż projektodawcy w centrum modelu stosunku pracy stawiają prawa człowieka pozostające w związku z wykonywaniem pracy zarobkowej, w tym prawo do pracy o charakterze bezwzględnym. Autorzy projektu nie wyjaśniają przy tym, w jakim rozumieniu używają samego pojęcia prawa człowieka (z jakiego aktu prawnego czerpią jego definicję), a jednocześnie czynią z niego pojęcie centralne w regulacji hierarchii źródeł prawa pracy. Według autorki, projekt kreuje także ,,antywolnościowy" model stosunku pracy.
\end{abstract}

Słowa kluczowe: stosunek pracy, prawa człowieka, Konstytucja RP, źródła prawa pracy.

* Dr, Uniwersytet Warszawski, Wydział Prawa i Administracji, Katedra Prawa Pracy i Polityki Społecznej; e-mail: e.maniewska@wpia.uw.edu.pl 


\section{Wstęp}

W marcu 2018 r. zostały zakończone prace Komisji Kodyfikacyjnej Prawa Pracy powołanej przez Radę Ministrów w sierpniu 2016 r. ${ }^{1}$ Efektem tych prac było przekazanie właściwemu Ministrowi ${ }^{2}$ projektów Kodeksu pracy ${ }^{3}$ oraz Kodeksu zbiorowego prawa pracy; obu wraz z uzasadnieniem. Jak dotą, podobnie jak projekty przedstawione w 2006 r. przez poprzednią Komisję Kodyfikacyjną Prawa Pracy ${ }^{4}$, nie zostały one przekazane do dalszych prac legislacyjnych.

Tym niemniej należy uwypuklić, że zakończenie prac nad wymienionymi projektami, będące ukoronowaniem starań także uznanych ekspertów nauki prawa pracy, skłania do dalszej dyskusji nad przedstawionymi propozycjami.

Niniejszy artykuł stanowi próbę zabrania głosu w tej dyskusji w zakresie modelu stosunku pracy ze szczególnym uwzględnieniem pożądanych - według opinii autorki - perspektyw budowania tego modelu na tle aktualnych tendencji zmian indywidualnego prawa pracy i osadzeniem w nich modelu stosunku pracy zaproponowanego w projekcie kodeksu pracy z $2018 \mathrm{r}$.

\section{Model stosunku pracy a model stosunku świadczenia pracy}

Zabranie głosu w dyskusji w odniesieniu do modelu stosunku pracy wymaga przede wszystkim doprecyzowania samego pojęcia tego modelu. Termin ten ostatnimi czasy stał się bowiem terminem wieloznacznym, gdyż nie można oprzeć się wrażeniu, że niekiedy jest rozumiany nie tyle jako model stosunku pracy sensu stricto, lecz szerzej - jako model stosunku świadczenia pracy. W pierwszym przypadku, mówiąc o modelu, mamy na myśli model stosunku świadczenia pracy podporządkowanej w rozumieniu art. $22 \S 1$ k.p., w drugim zaś chodzi nie tyle o model jednostkowy, odnoszący się tylko do jednej z podstaw świadczenia pracy (stosunku pracy), lecz o model złożony, w skład którego wchodzą modele odnoszące się do różnych podstaw zatrudnienia - głównie do stosunku pracy, ale także do stosunków cywilnoprawnych, w ramach których

1 Por. rozporządzenie Rady Ministrów z dnia 9 sierpnia 2016 r. w sprawie Komisji Kodyfikacyjnej Prawa Pracy (Dz.U. z 2016 r., poz. 1366).

2 Ministrowi Rodziny, Pracy i Polityki Społecznej.

3 Powoływany dalej także jako projekt lub projekt kodeksu. Tekst projektu dostępny na stronie: https://www.gov.pl/web/rodzina/bip-teksty-projektu-kodeksu-pracy-i-projektu-kodeksuzbiorowego-prawa-pracy-opracowane-przez-komisje-kodyfikacyjna-prawa-pracy

4 Rozporządzenie Rady Ministrów z dnia 20 sierpnia 2002 r. w sprawie utworzenia Komisji Kodyfikacyjnej Prawa Pracy (Dz.U. z 2002 r., nr 139, poz. 1167 ze zm.). 
jest świadczona praca (oczywiście przy założeniu tradycyjnego pojmowania zarówno stosunku pracy, jak i stosunków cywilnoprawnych będących podstawą świadczenia pracy zarobkowej).

W niniejszym opracowaniu przez model stosunku pracy będzie rozumiany model stosunku pracy sensu stricto, czyli odnoszący się do stosunku pracy zdefiniowanego jako taki przez przepisy prawa pracy (obecnie przez art. $22 \S 1$ k.p.).

Idąc dalej, ponieważ w każdym stosunku prawnym wyróżniamy takie jego elementy, jak: podmioty, przedmiot i treść, konsekwentnie zabierając głos w dyskusji odnośnie do kształtu modelu stosunku pracy, nieodzowne jest powiązanie go właśnie z tymi elementami. Należałoby zatem zająć stanowisko przynajmniej odnośnie do: podmiotów tego stosunku (kto lub „co” jest stroną tego stosunku), jaki jest jego przedmiot, czyli jakie zachowania społeczne (zachowania podmiotów tego stosunku) są związane z tym stosunkiem oraz jaki ma być kształt ogółu praw i obowiązków stron stosunku pracy (treść stosunku pracy).

W szczególności, jeśli chodzi o przedmiot stosunku pracy, to dotąd przyjmowało się, że są nim stosunki społeczne związane nie tyle ze świadczeniem jakiejkolwiek pracy, lecz jedynie pracy charakteryzującej się określonymi przymiotami, wynikającymi z formuły wprowadzonej do art. $22 \S 1$ k.p..$^{5}$ Jeśli zatem zmienimy tę formułę, to de facto zmienimy przedmiot stosunku pracy, a tym samym jego model. Analogicznie odnosi się to do pozostałych elementów stosunku pracy, czyli jego podmiotów, oraz ogółu ich praw i obowiązków.

\section{Perspektywy badawcze nauki prawa pracy}

Poruszając problematykę ogólnych perspektyw, z których formułowane są propozycje i które warunkują tendencje zmian modelu stosunku pracy, należy uwypuklić, że perspektywy badawcze najczęściej obecne w polskiej nauce prawa pracy nie są aż tak szerokie, jak perspektywy badawcze przyjmowane w innych krajach europejskich. Polska nauka w przeważającej części koncentruje się na takich zagadnieniach, jak: formuła podporządkowania osoby zatrudnionej, egzekwowanie zatrudnienia pracowniczego, delimitacja umów o zatrudnienie, podmiotowy i przedmiotowy zakresu ochrony minimalnej oraz, wiążący się z tym, zakres uniformizacji ochrony pracy podporządkowanej i pracy niepodporządkowanej czy koncepcja flexibility i flexicurity. Ostatnio więcej miejsca zaczęto też poświęcać samozatrudnieniu zależnemu i zatrudnieniu niepracow-

Por. np.: W. Szubert, Zarys prawa pracy, PWN, Warszawa 1972, s. 10; J. Piątkowski, Prawo stosunku pracy, TNOiK, Toruń 2009, s. 81-90. 
niczemu. Należy jednak także odnotować, że w polskiej nauce prawa pracy nie tak dawno pojawiła się próba reasumpcji tak ważnego zagadnienia, jak przynależność gałęziowa prawa pracy. Powstała nowatorska koncepcja, otwierająca zupełnie nową perspektywę badawczą, zgodnie z którą prawo pracy nie jest prawem prywatnym, lecz prawem publicznym ${ }^{6}$. Wiele miejsca poświęca się również analizie modelu stosunku pracy z punktu widzenia konstytucyjnej zasady społecznej gospodarki rynkowej (art. 20 Konstytucji) ${ }^{7}$.

Polska nauka prawa pracy, analizując problem modelu stosunku pracy, w mniejszym zakresie przyjmuje optykę badawczą wynikającą z zagadnienia równoważenia różnych wartości - praw socjalnych i swobód gospodarczych na poziomie unijnym („,miękkie” i ,twarde” europejskie prawo pracy) ${ }^{8}$. Ubogie są także odniesienia do wpływu na prawo pracy relewantnych procesów globalizacyjnych w ujęciu ponadeuropejskim ${ }^{9}$. Nieczęsto znajdujemy analizy uwzględniające podział na prawa demokratyczne jednostki, jej prawa cywilne i prawa socjalne ${ }^{10}$. W głównym nurcie polskiej nauki prawa pracy nie jest także obecne zagadnienie modelu stosunku pracy w kontekście zmian dotyczących sposobu, natury pracy, wpływu na nią nowoczesnych technologii i związanych z tym istotnych zagrożeń ${ }^{11}$. Nie jest także dostrzegany wątek zatrudniania emigrantów z innych kręgów kulturowych i religijnych ${ }^{12}$. Odnotowujemy także niewiele odniesień do koncepcji jednolitej umowy o pracę, obecnej w europejskim nurcie prawa pracy ${ }^{13}$.

6 A. Sobczyk, Wolność pracy $i$ władza, Wolters Kluwer, Warszawa 2015, s. 297-302.

7 Por. m.in. A. Sobczyk, Prawo pracy w świetle Konstytucji RP, Tom I. Teoria publicznego i prywatnego indywidualnego prawa pracy, C.H. Beck, Warszawa 2013, s. 38-46.

8 Por. jednak J. Ryszka, Prawa społeczne pracowników a prawa pracodawców-przedsiębiorców na rynku wewnętrznym Unii Europejskiej, C.H. Beck, Warszawa 2018, s. 367-370.

9 Dostrzega to przykładowo R. Del Punta: R. Del Punta, Labour Law on the Edge: Neoliberal Decline or Regeneration?, w: Z. Hajn, D. Skupień (red.), Przyszłość prawa pracy. Liber Amicorum. W pięćdziesięciolecie pracy naukowej Profesora Michała Seweryńskiego, Wydawnictwo Uniwersytetu Łódzkiego, Łódź 2015, s. 124-125. Por. także powołana tam dalsza literatura.

10 Por. w tym zakresie rozważania prowadzone przez J.M. Servaisa: J.M. Servais, Civil Rights and the Future of Labour Law, w: Z. Hajn, D. Skupień (red.), op. cit., s. 81-98.

11 Por. wąskie rozważania w tym zakresie M. Madej-Kalety: M. Madej-Kaleta, Nowoczesne technologie w gospodarce a ochrona pracowników w prawie pracy, w: M. Latos-Milkowska, L. Pisarczyk (red.), Prawo pracy. Między gospodarka a ochrona pracy. Ksiega jubileuszowa Profesora Ludwika Florka, Wolters Kluwer, Warszawa 2016, s. 252-262.

12 Por. P. Auvergnon, L'entreprise confrontée à la pluralité des expressions religieuses, w: Z. Hajn, D. Skupień (red.), op. cit., s. 153-162.

13 Por. jednak L. Mitrus, Jednolita umowa o pracę na czas nieokreślony?, w: Z. Hajn, D. Skupień (red.), op. cit., s. 209-211. 


\section{Pożądane perspektywy formułowania propozycji zmian modelu stosunku pracy w polskim prawie pracy}

Wydaje się, że w dyskusji dotyczącej modelu stosunku pracy, a ściślej w dyskusji dotyczącej budowania tego modelu, nie sposób pominąć zagadnienia pożądanych perspektyw formułowania propozycji zmian modelu stosunku pracy, $\mathrm{w}$ tym zmian modelu stosunku pracy w polskim prawie pracy.

W szczególności rozważenia wymaga, czy należy w tym względzie promować perspektywę holistyczną w jak najszerszej formule. Czy w jej ramach pożądane jest uwzględnianie głównie: praw człowieka (praw socjalnych), uwarunkowań antropologicznych czy wartości moralnych (w tym przykładowo społecznej nauki Kościoła), na czym w przeważającej części koncentrują się aktualne dyskusje dotyczące modelu stosunku pracy, czy też nie mniejsze znaczenie należy $\mathrm{w}$ tym względzie przypisywać także uwarunkowaniom wynikającym z procesów gospodarczych i normatywnych uregulowań ustroju gospodarczego w wymiarze lokalnym (społeczna gospodarka rynkowa w ujęciu krajowym lub europejskim) i ogólnoświatowym (globalizacja totalna) ${ }^{14}$.

Wiele przemawia także za uznaniem, że aktualne uwarunkowania globalne (nie tylko gospodarcze), kreujące ogromną zmienność i nieprzewidywalność wystąpienia różnych procesów, rodzą potrzebę przyjęcia nie tylko szerokiej, ale także zrównoważonej perspektywy konstruowania modelu stosunku pracy. Chodzi zatem o to, aby żadna $\mathrm{z}$ wymienionych perspektyw nie była dominująca lub nadmiernie dominująca. Przykładowo, błędem jest obserwowana nadmierna inflacja „prawnoczłowieczej” refleksji nad prawem, zwłaszcza wobec braku jednolitości co do samego pojęcia ,praw człowieka" i ich charakteru prawnego ${ }^{15}$.

Zdaje się także, że można zakładać, iż nadal będzie zapotrzebowanie na pracę podporządkowaną. Zakres i potrzeba jej ochrony w ujęciu współczesnym powinna być jednak analizowana także z perspektywy wolnościowej w takim znaczeniu, że istoty podporządkowania pracownika należy upatrywać w dużo węższym zakresie uprawnionej odmowy wykonania polecenia pracodawcy niż w stosunkach pracy niepodporządkowanej (w rozumieniu kodeksowym). Pracownik rezygnuje z większej dozy wolności niż inni zatrudnieni i dlatego powinien być bardziej chroniony niż inni zatrudnieni; zleceniobiorca (świadczący usługę) zachowuje większą wolność, ale kosztem słabszej ochrony. Warto się

4 Por. także. M. Gersdorf, Prawo zatrudnienia, LexisNexis, Warszawa 2013, s. 175-177.

15 Por. m.in.: J. Zajadło, Uniwersalizm praw człowieka w konstytucji-bezpieczne i niebezpieczne relatywizacje, Przegląd Sejmowy 2007/4, s. 95 i powołana tam dalsza literatura. 
zatem zastanowić, czy budując model stosunku pracy (czy szerzej - model stosunku świadczenia pracy), można ludzi pozbawiać tego wyboru. Wydaje się bowiem, że zbyt szerokie ograniczanie go godzi w „podstawowe” prawo człowieka do bycia wolnym.

Pożądany model stosunku pracy nie powinien również abstrahować od nowych form kontroli i nowych (także technologicznych) narzędzi podporządkowywania sobie pracownika przez pracodawcę. Zagadnienia te stanowią w ostatnich latach przedmiot intensywnych zainteresowań także polskiej nauki prawa pracy, ale nadal jest wiele do nadrobienia w tym obszarze.

Podkreślenia wymaga, że przy aktualnym rozumieniu podziału na prawo prywatne i publiczne, na obecnym etapie rozwoju prawa pracy trudna do zaakceptowania jest koncepcja opowiadająca się za umiejscowieniem prawa pracy (w tym modelu stosunku pracy) w sferze prawa publicznego, a nie - jak dotąd uznawano - w prawie prywatnym.

Otwarty pozostaje również problem wspólnotowości w stosunkach pracy, pozostający w związku z odmiennymi perspektywami patrzenia na prawo pracy w świetle dychotomii pomiędzy uznaniem, że w prawie pracy istotą pracy jest praca dla dobra i na rzecz pracodawcy a uznaniem, że istoty tej należy się doszukiwać w pracy dla dobra i na rzecz zakładu pracy - „wspólnoty” zakładu pracy (co poniekąd wiąże się także z katalogiem podmiotów stosunku pracy).

Warto również odnotować, że w polskiej nauce prawa pracy ostatnio silnie akcentuje się potrzebę zmiany metodologii tworzenia prawa pracy ${ }^{16}$. W tym ujęciu budowanie modelu stosunku pracy (modelu świadczenia pracy) powinno być poprzedzone solidną diagnozą empiryczną (badaniami statystycznymi o rozbudowanym spektrum kryteriów badawczych); uwzględniać przyjęte strategie rozwoju w wymiarze krajowym, europejskim, ale także zakładane modele rozwoju świata (ludzkości jako całości).

\section{Model stosunku pracy w projekcie kodeksu pracy z 2018 r.}

W kontekście wskazanych wyżej pożądanych perspektyw formułowania propozycji zmian modelu stosunku pracy w polskim prawie pracy trzeba wskazać, że projekt kodeksu pracy, przynajmniej deklaratywnie, zdaje się dostrzegać potrzebę obowiązywania modelu, który wyrasta z takiej optyki patrzenia na istotę prawa pracy, która uwzględnia różne, często przeciwstawne, punkty widze-

\footnotetext{
B. Godlewska-Bujok, Badania społeczne w tworzeniu prawa pracy. W poszukiwaniu modelu optymalnego, Praca i Zabezpieczenie Społeczne 2018/4, s. 4-9.
} 
nia. Można bowiem zakładać, że taka właśnie holistyczna perspektywa została - przynajmniej częściowo - uwidoczniona w treści art. 18 projektu. Przepis ten stanowi, że przy wykładni przepisów prawa pracy należy stosować w szczególności zasadę proporcjonalności, uwzględniając przede wszystkim prawo do pracy, wolność prowadzenia działalności gospodarczej, a także potrzebę realizacji celów społecznych.

Nie ma potrzeby prowadzenia wyrafinowanego wywodu, aby stwierdzić, że w ten sposób autorzy projektu zdają się opowiadać za takim modelem stosunku pracy, który realizuje między innymi te zasady konstytucyjne, które zostały ujęte w art. 2 i art. 20 ustawy zasadniczej, czyli: zasadę sprawiedliwości społecznej, zasadę proporcjonalności sensu largo oraz zasadę społecznej gospodarki rynkowej i wolności gospodarczej, do czego - wobec postulatów sformułowanych w punkcie 2 - należy się odnieść z pełną aprobatą.

Wśród szczegółowych rozwiązań proponowanych w projekcie, które wpisują się w tę konstatację, można wskazać przykładowo propozycje: dyferencjacji modelu stosunku pracy ze względu na ,wielkość” pracodawcy (np. art. 95 $\S 1$ ); zmianę zakresu ryzyka pracownika w związku z pracą wykonaną wadliwie (art. 212); rozluźnienie gorsetu zakazu zrzeczenia się prawa do wynagrodzenia (art. 214 i n.); umożliwienie złożenia przez pracownika wniosku o zmianę wymiaru czasu pracy określonego w umowie lub zatrudnienia go (kontynuacji zatrudnienia) na podstawie określonego rodzaju umowy o pracę (art. 229); skrócenie czasu, za który przysługuje wynagrodzenie chorobowe (art. 244).

Natomiast, w związku z krytyczną oceną galopującej inflacji ,,prawnoczłowieczej" refleksji nad prawem, z dezaprobatą należy się odnieść do zbyt silnie promowanego $\mathrm{w}$ projekcie modelu stosunku pracy akcentującego potrzebę realizacji przez prawo pracy przede wszystkim praw człowieka - jak to zostało niejasno ujęte - pozostających w związku z wykonywaniem pracy zarobkowej (art. $1 \S 1$ projektu).

Przy tej okazji trzeba także zwrócić uwagę na relację art. $1 \S 1 \mathrm{i}$ art. 18 projektu do art. 1 k.p., który stanowi, że „Kodeks pracy określa prawa i obowiązki pracowników i pracodawców".

Art. $1 \S 1$ projektu stanowi zaś, że „Kodeks pracy, zwany dalej „Kodeksem", reguluje prawa człowieka pozostające w związku z wykonywaniem pracy zarobkowej oraz związane z tym obowiązki”.

Wspomniany już przepis art. 18 projektu słusznie akcentuje zaś potrzebę stosowania przy wykładni przepisów prawa pracy zasady proporcjonalności, zasady wolności prowadzenia działalności gospodarczej oraz realizacji przez prawo pracy celów społecznych. Kontrowersyjne jest natomiast nadanie w tym przepisie 
szczególnej rangi prawu do pracy, które projektodawcy zdają się postrzegać jako prawo fundamentalne, wyprzedzające wszystkie inne prawa związane w wykonywaniem pracy zarobkowej oraz związanymi z nimi obowiązkami.

$\mathrm{W}$ tym miejscu warto jednak przypomnieć, że prawa do pracy w sensie ścisłym nie przewiduje żaden akt normatywny dotyczący praw człowieka - żaden akt nie posługuje się takim zwrotem. Znacząca część doktryny przyjmuje, iż prawo do pracy jest pojęciem języka prawniczego. W sensie materialnym, tak w prawie międzynarodowym, jak i na gruncie Konstytucji RP (por.: art. 24, art. 30 i art. 65 ustawy zasadniczej), stanowi jednak jedynie konglomerat różnych praw, z których każde jest objęte różną ochroną. Uznaje się, że „podstawowymi komponentami tego prawa są: swoboda wyboru pracy, zakaz pracy przymusowej lub obowiązkowej, zakaz dyskryminacji oraz dostęp do instrumentów realizowanej przez państwo polityki zatrudnienia"17 (por. także: art. 1 Europejskiej Karty Społecznej; art. 15 Karty Praw Podstawowych Unii Europejskiej).

Co więcej, nawet jeśli uprawnione byłoby wywiedzenie takiego prawa (w dosłownym tego słowa znaczeniu) z ratyfikowanych przez Polskę umów międzynarodowych (w tym konwencji) oraz z wiążących Polskę regulacji prawa pierwotnego Unii Europejskiej, co, jak wspomniano, jest wysoce wątpliwe, to należałoby przesądzić, czy przybiera ono formę zasady, czy reguły ${ }^{18}$.

W piśmiennictwie można jednak odnaleźć także poglądy odmienne, zgodnie z którymi prawo do pracy może być postrzegane jako publiczne prawo podmiotowe ${ }^{19}$, co w konsekwencji oznacza przyznanie jednostce publicznoprawnego roszczenia o zatrudnienie ${ }^{20}$.

Projektodawcy w art. 18 projektu użyli wprost zwrotu „prawo do pracy”. W świetle poczynionych uwag otwiera to dyskusję co do tego, jak należy ten zwrot interpretować; jej wynik będzie za sobą niósł daleko idące konsekwencje teoretyczne.

17 J. Polatyńska, E. Staszewska, Prawo do pracy, w: K.W. Baran (red.), System prawa pracy. Tom IX. Międzynarodowe publiczne prawo pracy. Standardy globalne., Wolters Kluwer, Warszawa 2019, s. 168-170. Por. także: A. Sobczyk, Prawo pracy w świetle Konstytucji RP. Tom II. Wybrane problemy i instytucje prawa pracy a konstytucyjne prawa i wolności człowieka, C.H. Beck, Warszawa 2013, s. 4-6.

18 Por.: R. Dworkin, Biorac prawa poważnie, Wydawnictwo Naukowe PWN, Warszawa 1998, s. 60-69; T. Gizbert-Studnicki, Zasady i reguly prawne, Państwo i Prawo 1988/3, s. 16-18; R. Alexy, Teoria praw podstawowych, Wydawnictwo Sejmowe, Warszawa 2010, s. 78; E. Maniewska, Obowiązi informacyjne pracodawcy wobec pracownika w umownym stosunku pracy, Wolter Kluwer, Warszawa 2013, s. 238-242.

19 Tak A. Sobczyk, Prawo pracy w świetle Konstytucji RP. Tom II..., s. 6.

20 Tak A. Sobczyk, Wolność pracy i władza, Wolters Kluwer, Warszawa 2015, s. 71. 
Pozostając w obszarze „obecności praw człowieka” w projekcie kodeksu pracy z 2018 r., nie sposób także nie zwrócić uwagi na problemy interpretacyjne związane z treścią art. $11 \mathrm{w}$ zW. z art. $1 \S 1$ projektu.

Przepis art. 11 projektu głosi, że ilekroć w Kodeksie jest mowa o przepisach prawa pracy, należy przez to rozumieć przepisy prawa powszechnie obowiązującego w zakresie określonym w art. $1 \S 1$. Niezależnie od tego, przepisami prawa pracy są także określające prawa i obowiązki stron stosunku pracy: postanowienia układów zbiorowych pracy, porozumień zbiorowych, jeżeli ustawa, która ich dotyczy, tak stanowi, oraz opartych na ustawie regulaminów, statutów i obwieszczeń.

Pomijając kwestię tzw. autonomicznych źródeł prawa pracy, odkodowując normatywne znaczenie części pierwszej tego przepisu, należałoby przyjąć, że prawem pracy są tylko te przepisy prawa powszechnego, które regulują prawa człowieka pozostające w związku z wykonywaniem pracy zarobkowej oraz związane z tym obowiązki.

Wobec niejasności związanych z samym pojęciem praw człowieka i charakterem prawnym praw człowieka ${ }^{21}$, wysoce mglista staje się również proponowana przez projektodawców podstawowa regulacja Kodeksu, dotycząca źródeł prawa pracy. Jeśli bowiem podzielić nakreślone powyżej wątpliwości, to na podstawie treści art. $12 \S 1 \mathrm{~W} \mathrm{ZW.} \mathrm{z} \mathrm{art.} 1 \S 1$ projektu niekiedy trudno będzie przesądzić, jakie przepisy stanowią źródło prawa pracy ${ }^{22}$. Może to prowadzić do dalszych istotnych problemów, związanych z zasadą semiimperatywności przepisów prawa pracy - art. 29 projektu ${ }^{23}$.

${ }^{21}$ Por.: A. Wróbel, Biorąc prawa socjalne poważnie, w: M. Zubik (red.), Minikomentarz dla maksiprofesora. Ksiegga jubileuszowa profesora Leszka Garlickiego, Wydawnictwo Sejmowe, Warszawa 2017, s. 347-351.

22 „Art. 12. § 1. Postanowienia układów zbiorowych pracy i porozumień zbiorowych oraz regulaminów, statutów i obwieszczeń nie mogą być mniej korzystne dla pracowników oraz innych osób nimi objętych niż przepisy Kodeksu i inne przepisy prawa powszechnie obowiązującego. $\S 2$. Przepis $\S 1$ nie ma zastosowania do układów zbiorowych pracy i porozumień zbiorowych, jeżeli przepisy ustawowe stanowią inaczej.

$\S 3$. Postanowienia porozumień zbiorowych nie mogą być mniej korzystne dla pracowników oraz innych osób nimi objętych od postanowień układów zbiorowych pracy.

$\S 4$. Postanowienia regulaminów i statutów nie mogą być mniej korzystne dla pracowników oraz innych osób nimi objętych od postanowień układów zbiorowych pracy i porozumień zbiorowych.

$\S 5$. W przypadkach, o których mowa w $\S 1,3$ i 4, postanowienia mniej korzystne nie obowiązują; zamiast nich stosuje się odpowiednie przepisy prawa pracy".

23 „Art. 29. § 1. Postanowienia umów o pracę oraz innych aktów, na których podstawie powstaje stosunek pracy, nie mogą być mniej korzystne dla pracownika niż przepisy prawa pracy. 
Istotne kontrowersje może także rodzić antywolnościowy charakter tych przepisów projektu, które w znaczącym stopniu eliminują swobodę wyboru podstawy prawnej świadczenia (wykonywania) pracy - por. art. $1 \S 2$, art. 7, art. 47 $\S 1$, art. $48 \mathrm{i}$ art. $50 \mathrm{w}$ związku z art. $177 \mathrm{i} \mathrm{n}$. projektu. Z przytoczonych regulacji wynika bowiem jasno, że ich projektodawcom przyświecał cel znacznego ograniczenia swobody wyboru podstawy prawnej świadczenia pracy zarobkowej. Konkretnie dotyczy to osób niebędących podmiotami gospodarczymi, czyli osób nieprowadzących jednoosobowej działalności gospodarczej w zakresie wykonywanej usługi. Taka osoba według projektodawców powinna mieć znacząco ograniczony wybór podstawy świadczenia pracy; poza enumeratywnie wyliczonymi w projekcie (nielicznymi) wyjątkami pozostawia się jej możność świadczenia pracy na rzecz innego podmiotu wyłącznie na podstawie stosunku pracy.

Niezwykle istotna jest nowa definicja stosunku pracy zawarta w projekcie. Warto bowiem zwrócić uwagę, że pomimo utrzymania tradycyjnego wyznacznika stosunku pracy, jakim jest praca pod kierownictwem pracodawcy, wyeliminowano $\mathrm{z}$ niej formułę zobowiązania się przez pracownika do pracy na rzecz pracodawcy ${ }^{24}$, co zdaje się korespondować z ferowanymi przez niektórych przedstawicieli doktryny tezami, że istotą pracy w ramach stosunku pracy nie jest praca dla dobra i na rzecz pracodawcy, lecz praca dla dobra i na rzecz zakładu pracy (por. także art. 22 projektu ${ }^{25}$ ), co w dalszej konsekwencji mogłoby rodzić potrzebę szerszej refleksji nad relacjami w układzie: pracownik - pracodawca, pracownik - zakład pracy (,wspólnota” zakładu pracy) i pracodawca - zakład pracy („wspólnota” zakładu pracy). Przy okazji tej refleksji mogłoby dojść do wypracowania całkowicie nowego spojrzenia na zagadnienie podmiotów stosunku pracy. Jeśli bowiem przyjmujemy taki model stosunku pracy, że beneficjentem pracy (,dla dobra i na rzecz”) nie jest pracodawca, ale zakład pracy (jego „wspólnota'), to znaczy, że zakład pracy (,wspólnota” zakładu pracy) stanowi obok pracownika i pracodawcy kolejny podmiot stosunku pracy.

$\mathrm{W}$ definicji zawartej $\mathrm{w}$ projekcie brakuje też elementu zobowiązania się pracownika do wykonywania pracy w miejscu i czasie wyznaczonym przez pracodawcę, co z kolei zdaje się oznaczać, że uprawnienie pracodawcy do wy-

$\S 2$. Postanowienia umów i aktów, o których mowa w $\S 1$, mniej korzystne dla pracownika niż przepisy prawa pracy są nieważne; zamiast nich stosuje się odpowiednie przepisy prawa pracy".

24 Por. art. $45 \S 1$ projektu.

25 „Art. 22. Pracownik i pracodawca mają obowiązek dbać o dobro zakładu pracy”. Inne konsekwencje z treści art. 45 w zw. z art. 22 projektu wyciąga K. Jaśkowski, por. K. Jaśkowski, Podstawy wykonywania pracy wedlug projektu kodeksu pracy z $2018 \mathrm{r}$. 
znaczania miejsca i czasu pracy miałoby wynikać z jego prawa do kierowania pracownikiem. Jak już wskazano, definicja stosunku pracy w projekcie nadal posługuje się bardzo nieostrym pojęciem kierownictwa, które, jak wiadomo, zostało w pewnych formach dopuszczone także wobec wykonywania pracy w ramach umowy o świadczenie usług i przez to zostało uznane przez wielu przedstawicieli nauki prawa pracy za pozbawione przymiotu bycia differentia specifica stosunku pracy ${ }^{26}$. Projektodawcy, utrzymując ten element definicji stosunku pracy, opowiedzieli się zatem za brakiem potrzeby rozwiązań progresywnych w tym względzie, skazując podmioty obrotu prawnego na dalsze niejasności w obrębie definicji, która bez wątpienia pozostaje definicją centralną dla całego prawa pracy.

Jak wskazano, pożądany model stosunku pracy powinien również uwzględniać fakt pojawienia się w praktyce nowych form kontroli i nowych (także technologicznych) narzędzi podporządkowywania sobie pracownika przez pracodawcę.

W tym kontekście należy z pełną aprobatą odnieść się do pochylenia się nad tą kwestią twórców projektu kodeksu pracy z 2018 r., czego wyrazem są art. $57 \mathrm{i} \mathrm{n.} \mathrm{projektu.}$

Na koniec z przykrością trzeba przypomnieć, że autorzy przedłożonego projektu przyznali publicznie, że nie dano im możliwości korzystania ani z badań eksperckich, ani z badań statystycznych czy innych rozbudowanych instrumentów badawczych. W związku z tym trudno o tezę, że stworzenie ostatecznego kształtu projektu zostało poprzedzone solidną diagnozą empiryczną regulowanych stosunków społecznych.

\section{Zakończenie}

Z projektu kodeksu pracy z 2018 r. bez wątpienia wyłania się tendencja do budowania modelu stosunku pracy z perspektywy holistycznej. Zarazem jednak jest to perspektywa niezrównoważona, gdyż projektodawcy w centrum modelu stosunku pracy stawiają prawa człowieka pozostające w związku z wykonywaniem pracy zarobkowej, nie wyjaśniając przy tym, które to prawa człowieka uważają za te, które są związane $\mathrm{z}$ wykonywaniem pracy zarobkowej, i w jakim rozumieniu używają

26 Por. zamiast wielu: T. Duraj, Ewolucja pracowniczego podporzadkowania jako cechy konstrukcyjnej stosunku pracy w świetle przepisów prawa pracy, w: A. Kosut, W. Perdeus (red.), Przemiany prawa pracy. Od kodyfikacji do wspótczesności. Księga jubileuszowa w siedemdziesięciolecie urodzin Profesor Teresy Liszcz, Studia Iuridica Lublinensia 2015/XXIV/3, Lublin, s. 159-179. 
samego pojęcia praw człowieka (z jakiego aktu prawnego czerpią ich definicje). Z kluczowego w tym względzie przepisu art. $1 \S 1$ projektu dodatkowo wynika, że prawa pracownika wyraźnie „dominują” nad prawami pracodawcy, którego zdaje się dotyczyć dopiero art. 18 projektu (przedostatni artykuł przepisów wstępnych).

Oprócz tego projektodawcy gwarantują w kodeksie prawo do pracy, zdając się je postrzegać jako prawo człowieka, które powinno być przestrzegane bezwzględnie, co budzi istotne zastrzeżenia także wobec braku zgody, co do bytu takiego prawa i charakteru prawnego samych praw człowieka.

Z projektu wyłania się także „antywolnościowy” model stosunku pracy, czyli silnie ograniczający swobodę wyboru podstaw prawnych wykonywania pracy zarobkowej, a tym samym w znacznym stopniu zmuszający ludzi do świadczenia pracy zarobkowej wyłącznie w gorsecie silnego podporządkowania podmiotowi zatrudniającemu.

Jednak okolicznością najistotniejszą - bo najbardziej nowatorską - odnoszącą się do modelu stosunku pracy zawartego w projekcie, jest fakt wprowadzenia do tego modelu "nowego" - obok pracodawcy i pracownika - podmiotu tego stosunku, którym jest zakład pracy (,wspólnota” zakładu pracy). Bez wątpienia stanowi to refleks starej i, co wymaga podkreślenia, już dawno odrzuconej przez naukę prawa pracy, koncepcji stosunku pracy opartej nie na teorii zobowiązaniowej, ale na teorii wspólnoty ${ }^{27}$. Koncepcja ta zdaje się być w projekcie znacząco wskrzeszana ${ }^{28}$.

\section{Bibliografia}

\section{Akty prawne}

Konstytucja Rzeczypospolitej Polskiej z dnia 2 kwietnia 1997 r. (Dz.U. nr 78, poz. 483 ze zm.) Rozporządzenie Rady Ministrów z dnia 20 sierpnia 2002 r. w sprawie utworzenia Komisji Kodyfikacyjnej Prawa Pracy (Dz.U. z 2002 r., nr 139, poz. 1167 ze zm.).

Rozporządzenie Rady Ministrów z dnia 9 sierpnia 2016 r. w sprawie Komisji Kodyfikacyjnej Prawa Pracy (Dz.U. z 2016 r., poz. 1366).

\section{Opracowania}

Alexy Robert, Teoria praw podstawowych, Wydawnictwo Sejmowe, Warszawa 2010.

27 Por.: M. Święcicki, Stosunek pracy, w: Z. Salwa, W. Szubert, M. Święcicki, Podstawowe problemy prawa pracy, PWN, Warszawa 1957 s. 74-82; W. Szubert, O charakterze prawnym stosunku pracy, Państwo i Prawo 1964/7, s. 81-96; J. Stelina, Przedmiot prawa pracy, w: K.W. Baran (red.), Zarys systemu prawa pracy. Tom. I. Część ogólna prawa pracy, Wolters Kluwer, Warszawa 2010, s. 99-100. 
Auvergnon Philippe, L'entreprise confrontée à la pluralité des expressions religieuses, w: Zbigniew Hajn, Dagmara Skupień (red.), Przyszłość prawa pracy. Liber Amicorum. W pięćdziesięciolecie pracy naukowej Profesora Michała Seweryńskiego, Wydawnictwo Uniwersytetu Łódzkiego, Łódź 2015, s. 153-162.

Del Punta Riccardo, Labour Law on the Edge: Neoliberal Decline or Regeneration?, w: Zbigniew Hajn, Dagmara Skupień (red.), Przyszłość prawa pracy. Liber Amicorum. W pięćdziesięciolecie pracy naukowej Profesora Michała Seweryńskiego, Wydawnictwo Uniwersytetu Łódzkiego, Łódź 2015, s. 124-125.

Duraj Tomasz, Ewolucja pracowniczego podporządkowania jako cechy konstrukcyjnej stosunku pracy w świetle przepisów prawa pracy, w: Anna Kosut, Wiesław Perdeus (red.), Przemiany prawa pracy. Od kodyfikacji do wspótczesności. Księga jubileuszowa w siedemdziesięciolecie urodzin Profesor Teresy Liszcz, Studia Iuridica Lublinensia 2015/XXIV/3, Lublin, s. $159-179$.

Dworkin Ronald, Biorac prawa poważnie, Wydawnictwo Naukowe PWN, Warszawa 1998.

Gersdorf Malgorzata, Prawo zatrudnienia, LexisNexis, Warszawa 2013.

Gizbert-Studnicki Tomasz, Zasady i reguły prawne, Państwo i Prawo 1988/3, s. 16-18.

Godlewska-Bujok Barbara, Badania społeczne w tworzeniu prawa pracy. W poszukiwaniu modelu optymalnego, Praca i Zabezpieczenie Społeczne 2018/4, s. 4-9.

Jaśkowski Kazimierz, Podstawy wykonywania pracy wedtug projektu kodeksu pracy z 2018 r.

Madej-Kaleta Marta, Nowoczesne technologie w gospodarce a ochrona pracowników w prawie pracy, w: Monika Latos-Miłkowska, Łukasz Pisarczyk (red.), Prawo pracy. Między gospodarka a ochrona pracy. Ksiega jubileuszowa Profesora Ludwika Florka, Wolters Kluwer, Warszawa 2016, s. 252-262.

Maniewska Eliza, Obowiązki informacyjne pracodawcy wobec pracownika w umownym stosunku pracy, Wolter Kluwer, Warszawa 2013.

Mitrus Leszek, Jednolita umowa o pracę na czas nieokreślony?, w: Zbigniew Hajn, Dagmara Skupień (red.), Przyszłość prawa pracy. Liber Amicorum. W pięćdziesięciolecie pracy naukowej Profesora Michała Seweryńskiego, Wydawnictwo Uniwersytetu Łódzkiego, Łódź 2015, s. 209-211.

Piątkowski Jan, Prawo stosunku pracy, TNOiK, Toruń 2009.

Połatyńska Joanna, Staszewska Ewa, Prawo do pracy, w: Krzysztof W. Baran (red.), System prawa pracy. Tom IX. Międzynarodowe publiczne prawo pracy. Standardy globalne, Wolters Kluwer, Warszawa 2019, s. 168-170.

Ryszka Joanna, Prawa społeczne pracowników a prawa pracodawców-przedsiębiorców na rynku wewnętrznym Unii Europejskiej, C.H. Beck, Warszawa 2018.

Servais Jean-Michel, Civil Rights and the Future of Labour Law, w: Zbigniew Hajn, Dagmara Skupień (red.), Przyszłość prawa pracy. Liber Amicorum. W pięćdziesięciolecie pracy naukowej Profesora Michała Seweryńskiego, Wydawnictwo Uniwersytetu Łódzkiego, Łódź 2015, s. 81-98.

Sobczyk Arkadiusz, Prawo pracy w świetle Konstytucji RP, Tom I. Teoria publicznego i prywatnego indywidualnego prawa pracy, C.H. Beck, Warszawa 2013.

Sobczyk Arkadiusz, Prawo pracy w świetle Konstytucji RP. Tom II. Wybrane problemy i instytucje prawa pracy a konstytucyjne prawa $i$ wolności człowieka, C.H. Beck, Warszawa 2013.

Sobczyk Arkadiusz, Wolność pracy $i$ władza, Wolters Kluwer, Warszawa 2015. 
Stelina Jakub, Przedmiot prawa pracy, w: Krzysztof W. Baran (red.), Zarys systemu prawa pracy. Tom. I. Część ogólna prawa pracy, Wolters Kluwer, Warszawa 2010, s. 99-100.

Szubert Waclaw, O charakterze prawnym stosunku pracy, Państwo i Prawo 1964/7, s. 81-96.

Szubert Wacław, Zarys prawa pracy, PWN, Warszawa 1972.

Święcicki Maciej, Stosunek pracy, w: Zbigniew Salwa, Wacław Szubert, Maciej Święcicki, Podstawowe problemy prawa pracy, PWN, Warszawa 1957, s. 74-82.

Wróbel Andrzej, Biorac prawa socjalne poważnie, w: Marek Zubik (red.), Minikomentarz dla maksiprofesora. Ksiega jubileuszowa profesora Leszka Garlickiego, Wydawnictwo Sejmowe, Warszawa 2017, s. 347-351.

Zajadło Jerzy, Uniwersalizm praw człowieka w konstytucji - bezpieczne i niebezpieczne relatywizacje, Przegląd Sejmowy 2007/4, s. 95.

\title{
Eliza MANIEWSKA
}

\section{THE EMPLOYMENT RELATIONSHIP MODEL AND A DRAFT OF THE LABOUR CODE FROM 2018}

\begin{abstract}
Background: Research perspectives adopted in Polish and European labour law science regarding the employment relationship model (a model of rendering work [under employment relationship]). Research purpose: To determine the desired perspectives for formulating the employment relationship model and to compare them with the proposal to change the employment relationship model contained in the draft of the Polish Labour Code from 2018.

Methods: The Author uses a mixed method, taking into account, in addition to the formal and dogmatic method, the following methods: comparative; philosophical and anthropological.

Conclusions: The Author indicates what - in her opinion - should be perspectives for formulating proposals for changes in the employment relationship model in Polish labour law. She believes that a holistic perspective should be adopted that takes into account mainly human rights (social rights), anthropological conditions, moral values, factors resulting from economic processes, as well as normative regulations of the economic system in the national, European and global dimensions. She postulates that none of these perspectives be dominant or excessively dominant, and that a balanced approach is needed. The desired model of employment relationship should also not abstract from new forms of control or new (also technological) tools for an employer to subordinate the employee. It is also necessary to leave people the choice of whether and to what extent they want to be subordinated to the employer.

Taking this into account, the Author refers to selected elements of the employment relationship model that have emerged from the proposals contained in the draft of the Polish Labour Code from 2018. She imputes to the draft designers that they place at the center of the employment relationship model human rights related to paid employment, including the absolute right to work. At the same time, the authors of the project have not explained in what sense they use the very concept of human rights (from which legal act they derive its definition) and at the same time make it the central concept in the regulation of the hierarchy of sources of labour law. According to the Author, the project also creates an "anti-libertarian" model of employment relationship.
\end{abstract}

Keywords: employment relationship model, human rights, Constitution of the Republic of Poland, sources of law. 